\title{
GAMBARAN MORTALITAS PASIEN DI RUANG PICU RSUD ABDUL WAHAB SJAHRANIE SAMARINDA PERIODE 2016-2017
}

\author{
Siti Hajari ${ }^{1}$ Endang Sawitri ${ }^{2}$, Annisa Muhyi ${ }^{3}$,Hary Nugroho ${ }^{4}$ \\ ${ }^{1}$ Program Studi Kedokteran, Fakultas Kedokteran, Universitas Mulawarman \\ ${ }^{2}$ Laboratorium Ilmu Fisiologi, Fakultas Kedokteran, Universitas Mulawarman \\ ${ }^{3}$ Laboratorium Ilmu Kesehatan Anak, Fakultas Kedokteran, Universitas Mulawarman \\ ${ }^{4}$ Laboratorium Anatomi, Fakultas Kedokteran, Universitas Mulawarman \\ Email: sitihajari@gmail.com
}

\begin{abstract}
Pediatric Intensive Care Unit (PICU) is a spscial functional caring unit that provides intensive treatments for infants and children. Human resources in PICU will do anything they can to save patients. This research try to describe the mortality patients in the PICU room of RSUD Abdul Wahab Sjahranie Samarinda in the 2016-2017 period. We plan to use observational descriptive study using cross sectional data from medical records of 2016-2017 PICU patients who had fulfilled the inclusion criteria of 143 samples. The results showed that patients died at the age of $<60$ months (49.3\%) and $\geq 60$ months (18.1\%), male sex died as much (34.4\%) and (32.9\%) in women, the diagnosis was pneumonia (27.3\%), GIT abnormalities (19.6\%) and encephalitis (8.4\%). Duration of treatment for $<48$ hours (25.2\%), 48-120 hours (26.6\%) and $>120$ hours (48.3\%), then led to death caused were respiratory failure (48.2\%), septic shock (21.7\%) and multiorgan failure (10.5\%). The majority of patients who died in PICU within $<60$ months, men, diagnosis of pneumonia, length of treatment> 120 hours with the most common cause was respiratory failure.
\end{abstract}

Keyword : PICU, age, sex, diagnose, length of stay, cause of death

\section{PENDAHULUAN}

Pediatric Intensive Care Unit atau PICU merupakan satu bagian khusus di rumah sakit yang menyediakan fasilitas perawatan medis bermutu tinggi bagi bayi dan anak dengan kondisi tertentu (Aisyah, 2010). Unit khusus ini dirancang terpisah untuk penanganan bayi dan anak yang mengalami gangguan medis, bedah atau trauma dengan kondisi yang mengancam jiwa sehingga memerlukan perawatan intensif, observasi yang bersifat komprehensif dan perawatan khusus (Alfana dkk, 2015). Unit ini dapat menjadi tempat perawatan dengan kegagalan organ yang disebabkan penyakit akut atau trauma dengan kondisi yang diperkirakan reversibel (Barry et al, 2010).

Penelitian di Hospital Israelita Albert Einstein Brazil menunjukkan jumlah pasien yang masuk ruang PICU rata-rata $69,3 \%$ per tahun dan jumlah pasien terbanyak berada pada bulan April, Agustus, dan Oktober. Rata-rata lama tinggal di rumah sakit berkisar 
antara 9 sampai 19 hari (Brooten et al, 2016). Kelompok usia terbanyak yang masuk ruang PICU adalah usia 1 sampai 4 tahun (Brooten et al, 2016). Sekitar $55 \%$ dari semua anak yang meninggal di ruang PICU adalah laki-laki, usia ratarata adalah 2 tahun dan sepertiga berusia kurang dari satu tahun (Burns et al, 2014).

Penelitian di Inggris melaporkan pasien yang dirawat di ruang PICU terbanyak menderita penyakit kardiovaskular diikuti oleh penyakit pernapasan dan neurologis. Akan tetapi, penyakit pernapasan adalah penyebab tersering untuk perawatan di ruang PICU (Brooten et al , 2016). Di Indonesia penyakit terbanyak yang di rawat di ruang PICU adalah diare, pneumonia, enterokolitis, meningitis, penyakit jantung bawaan, status epileptikus, demam berdarah, campak, tenggelam, malaria, leukemia dan lain lain (Djajakusli dkk, 2017).

Hampir 2,5 milyar kematian disebabkan oleh diare dalam dua tahun pertama kehidupan, dan diare juga menyebabkan $17 \%$ kematian anak balita di dunia. Tercatat 1,8 milyar orang meninggal setiap tahun karena penyakit diare (termasuk kolera), banyak yang disertai komplikasi seperti malnutrisi, retardasi pertumbuhan, dan kelainan imun (El Hamshary et al, 2016). Gagal napas dan malaria adalah penyebab kematian yang paling umum pada anak di bawah usia lima tahun di negaranegara berkembang (Frankel \& Dicarlo, 2003).

Hasil penelitian di Amerika Serikat mendapatkan lebih dari 55.000 anak meninggal setiap tahunnya dan sebagian besar dari itu meninggal di ruang PICU (Hardisman, 2008). Sekitar $70 \%$ pasien meninggal setelah pemotongan tali pusar atau penarikan perawatan penunjang hidup, $16 \%$ didiagnosis mati batang otak dan $14 \%$ meninggal setelah usaha resusitasi yang tidak berhasil (Burns et al, 2014). Gagal napas adalah penyakit yang paling banyak pada pasien yang dirawat di ruang PICU dan tingkat kematian tertinggi dikaitkan dengan penyakit neoplastik ((Brooten et al, 2016). Diare merupakan penyebab kematian terbanyak di ruang PICU, sedangkan pneumonia merupakan penyakit penyebab kematian tertinggi kedua setelah diare diantara balita. Hal ini menunjukan bahwa diare dan pneumonia merupakan penyakit yang menjadi masalah kesehatan masyarakat utama yang berkontribusi terhadap tingginya angka kematian balita di Indonesia (Horowitz \& Kenneth, 2007). Berdasarkan data di atas, kematian anak yang dirawat di ruang PICU cukup tinggi dan sejauh ini belum ditemukan publikasi hasil penelitian tentang gambaran mortalitas di ruang PICU RSUD Abdul Wahab Sjahranie, sehingga peneliti tertarik untuk melakukan penelitian ini.

\section{METODE PENELITIAN}

Penelitian ini merupakan jenis penelitian deskriptif observasional dengan desain Cross Sectional yang bertujuan untuk memberikan gambaran tentang mortalitas pasien di ruang PICU RSUD Abdul Wahab Sjahranie Samarinda. Dalam penelitian ini cara pengambilan sampel dilakukan dengan menggunakan teknik total sampling dengan jumlah sampel sebanyak 143 sampel. Sampel akan diambil sesuai dengan kriteria inklusi dan eksklusi. 
Kriteria Inklusi :

1) Pasien yang meninggal saat menjalani perawatan di ruang PICU RSUD Abdul Wahab Sjahranie Samarinda Periode 2016-2017.

2) Pasien PICU RSUD Abdul WAHAB Sjahranie berusia lebih dari 1 bulan sampai 18 tahun.

Kriteria eksklusi adalah pasien yang data rekam medisnya tidak lengkap.

Cara pengambilan data menggunakan data sekunder berupa yang diperoleh dari lembar observasi di rekam medik pasien yang dirawat dan yang meninggal di ruang PICU RSUD Abdul Wahab Sjahranie Samarinda sepanjang tahun 2016-2017. Pengolahan data dilakukan dengan 3 tahapan, yaitu input data, edit data dan tabulasi data menggunakan Microsoft Excel 2007 dan SPSS Statistic Versi 2032 bit. Penyajian data dilakukan dalam bentuk narasi, tabel dan/atau diagram, frekuensi dan persentase.

\section{HASIL DAN PEMBAHASAN}

Dari hasil penelitian ini didapatkan hasil sebagai berikut.

Gambar 1.Gambaran Angka Kejadian Pasien yang di Rawat di PICU

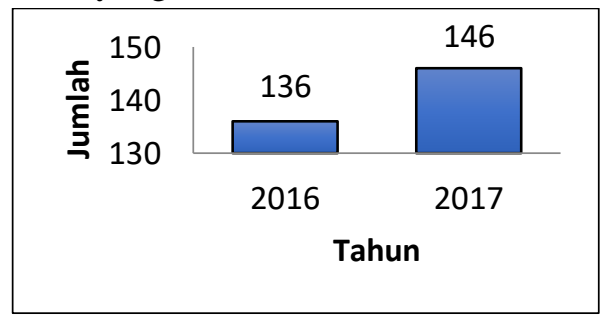

Jumlah pasien yang dirawat di ruang PICU pada tahun 2016 sebanyak 136 pasien dan tahun 2017 sebanyak 146 pasien sehingga total 282 pasien yang dirawat sepanjang tahun 2016-2017 di ruang PICU RSUD AWS Samarinda (gambar 1).
Gambar 2. Gambaran Angka Kejadian Pasien yang Meninggal di PICU

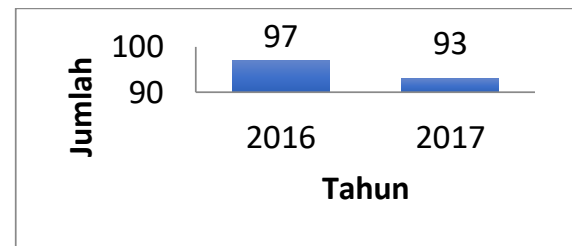

Jumlah pasien yang meninggal di ruang PICU pada tahun 2016 sebanyak 97 pasien dan pada tahun 2017 sebanyak 93 pasien dengan total 190 pasien yang meninggal pada tahun 2016 dan tahun 2017 di ruang PICU RSUD AWS Samarinda (gambar 2).

Gambar 3.Gambaran Usia Pasien PICU yang Meninggal

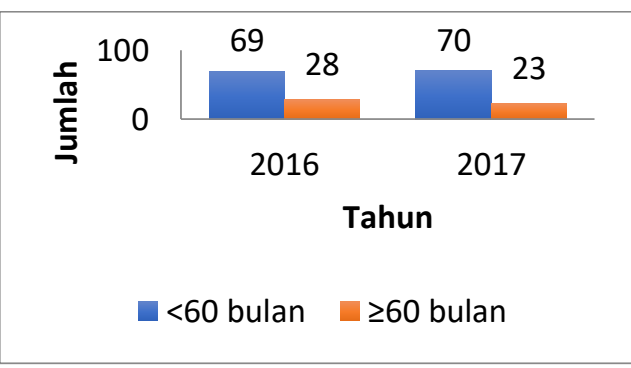

Gambar 3 memperlihatkan bahwa distribusi pasien PICU yang meninggal berdasarkan usia di RSUD AWS Samarinda pada tahun 2016 dan tahun 2017 yaitu jumlah pasien yang meninggal terbanyak pada usia kurang dari 60 bulan dengan jumlah 69 pasien pada tahun 2016 dan 70 pasien pada tahun 2017, selebihnya pasien dengan usia lebih dari sama dengan 60 bulan dengan jumlah 28 pasien pada tahun 2016 dan 23 pasien pada tahun 2017. Gambar 4.Gambaran Jenis Kelamin Pasien PICU yang Meninggal 


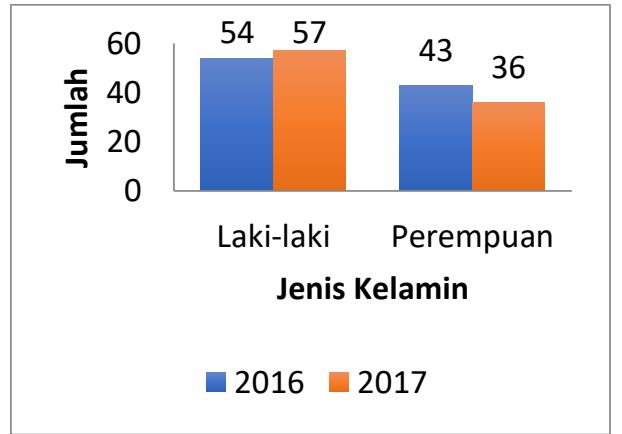

Gambar 4 memperlihatkan bahwa distribusi pasien PICU yang meninggal berdasarkan jenis kelamin di RSUD AWS Samarinda yaitu jumlah pasien laki-laki sebanyak 54 pasien dan perempuan sebanyak 43 pasien pada tahun 2016. Pada tahun 2017 jumlah pasien laki-laki sebanyak 57 pasien dan perempuan sebanyak 36 pasien.

Tabel 1. Gambaran Diagnosis Pasien PICU yang Meninggal

\begin{tabular}{|c|c|c|c|}
\hline Sistem & $\begin{array}{l}\text { Diagnosi } \\
\mathrm{s}\end{array}$ & $\begin{array}{c}\text { Freku } \\
\text { ensi } \\
\text { (n) }\end{array}$ & $\begin{array}{c}\text { Persen } \\
\text { tase } \\
(\%)\end{array}$ \\
\hline \multirow[t]{5}{*}{$\begin{array}{l}\text { Pulmona } \\
1\end{array}$} & $\begin{array}{l}\text { Pneumon } \\
\text { ia }\end{array}$ & 39 & $27,3 \%$ \\
\hline & $\begin{array}{l}\text { Efusi } \\
\text { Pleura }\end{array}$ & & $2,1 \%$ \\
\hline & TB Paru & 2 & $1,4 \%$ \\
\hline & $\begin{array}{l}\text { Empiem } \\
\text { a Thorax }\end{array}$ & 1 & $0,7 \%$ \\
\hline & $\begin{array}{l}\text { Asma } \\
\text { Episodik } \\
\text { Persisten } \\
\text { Derajat } \\
\text { Berat }\end{array}$ & 1 & $0,7 \%$ \\
\hline \multirow{2}{*}{$\begin{array}{l}\text { Kardiova } \\
\text { skular }\end{array}$} & DSS & 8 & $5,6 \%$ \\
\hline & $\begin{array}{l}\text { PJB } \\
\text { Sepsis }\end{array}$ & $\begin{array}{l}6 \\
5\end{array}$ & $\begin{array}{l}4,2 \% \\
3,5 \%\end{array}$ \\
\hline \multirow[t]{2}{*}{$\begin{array}{l}\text { Saluran } \\
\text { Pencerna } \\
\text { an }\end{array}$} & $\begin{array}{l}\text { Kelainan } \\
\text { GIT }\end{array}$ & 28 & $19,6 \%$ \\
\hline & GEA & 3 & $2,1 \%$ \\
\hline \multirow[t]{2}{*}{$\begin{array}{l}\text { Neurolog } \\
\text { is }\end{array}$} & $\begin{array}{l}\text { Encephal } \\
\text { itis }\end{array}$ & 12 & $8,4 \%$ \\
\hline & $\begin{array}{l}\text { Perdarah } \\
\text { an }\end{array}$ & 10 & $7 \%$ \\
\hline
\end{tabular}

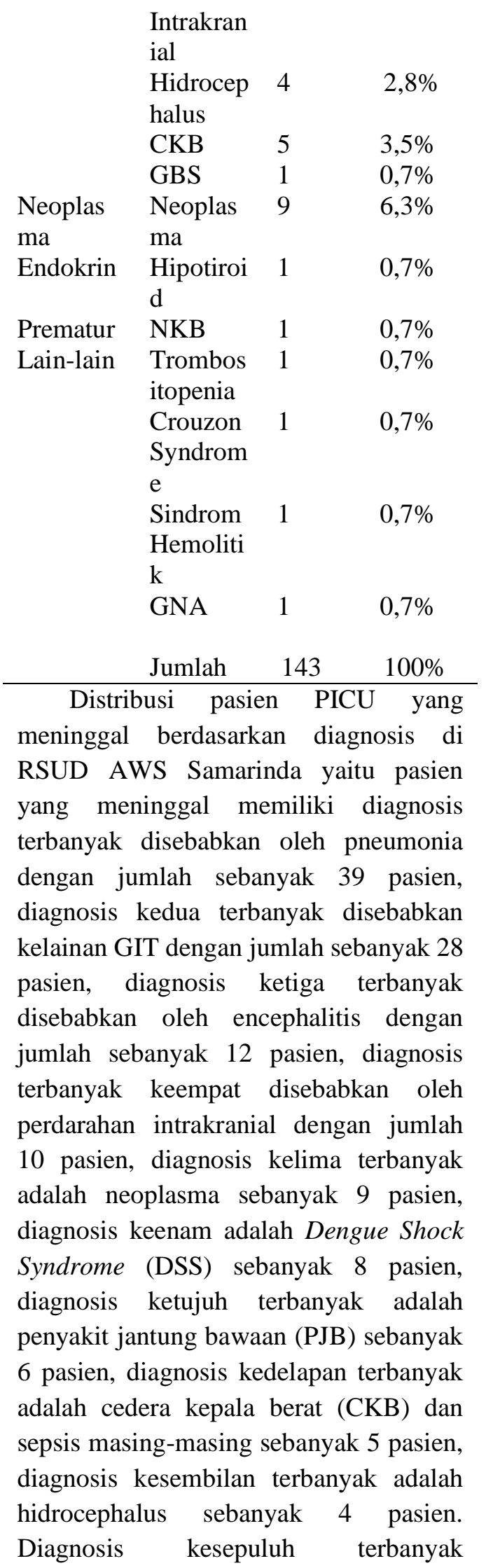


gastroenteritis akut (GEA) dan efusi pleura masing-masing sebanyak 3 pasien, diagnosis kesebelah terbanyak adalah TB paru sebanyak 2 pasien dan sisanya adalah empiema thorax, trombositopenia, hipotiroid, NKB, asma episodik persisten derajat berat, GBS, crouzon syndrome, sindrom hemolitik dan GNA dengan jumlah masing-masing sebanyak 1 pasien (tabel 1).

Tabel 2. Gambaran Lama Perawatan Pasien PICU yang Meninggal

\begin{tabular}{lll}
\hline $\begin{array}{l}\text { Lama } \\
\text { Perawatan } \\
(\text { Jam) }\end{array}$ & $\begin{array}{l}\text { Frekuensi } \\
(\mathbf{n})\end{array}$ & $\begin{array}{l}\text { Persentase } \\
(\%)\end{array}$ \\
\hline$<48$ & 36 pasien & $25,2 \%$ \\
$48-120$ & 38pasien & $26,6 \%$ \\
$>120$ & 69 pasien & $48,3 \%$ \\
Jumlah & 143 pasien & $100 \%$ \\
\hline
\end{tabular}

Distribusi pasien PICU yang meninggal berdasarkan lama perawatan di RSUD AWS Samarinda yaitu pasien yang meninggal memiliki lama perawatan terbanyak pada waktu lebih dari 120 jam dengan jumlah sebanyak 69 pasien, lama perawatan kedua terbanyak berada pada waktu 48 jam-120 jam dengan jumlah sebanyak 38 pasien dan yang paling sedikit berada pada waktu kurang dari 48 jam dengan jumlah 36 pasien (tabel 2).

Tabel 3. Gambaran Penyebab Kematian Pasien PICU yang Meninggal

\begin{tabular}{lcc}
\hline $\begin{array}{c}\text { Penyebab } \\
\text { Kematian }\end{array}$ & $\begin{array}{c}\text { Frekuens } \\
\text { i (n) }\end{array}$ & $\begin{array}{c}\text { Persentas } \\
\text { e (\%) }\end{array}$ \\
\hline Gagal Napas & 69 & $48,2 \%$ \\
Syok Sepsis & 31 & $21,7 \%$ \\
Gagal Multi & 15 & $10,5 \%$ \\
Organ & & \\
Syok & 13 & $9,1 \%$ \\
Kardiogenik & & \\
Herniasi & 4 & $2,8 \%$ \\
\hline
\end{tabular}

\begin{tabular}{|c|c|c|}
\hline $\begin{array}{l}\text { Tentorial } \\
\text { Syok } \\
\text { Hipovolemik }\end{array}$ & 2 & $1,4 \%$ \\
\hline $\begin{array}{l}\text { Penyebab } \\
\text { Kematian }\end{array}$ & $\begin{array}{l}\text { Frekuens } \\
\quad \text { i (n) }\end{array}$ & $\begin{array}{c}\text { Persentas } \\
\text { e }(\%)\end{array}$ \\
\hline $\begin{array}{l}\text { Mati Batang } \\
\text { Otak }\end{array}$ & 2 & $1,4 \%$ \\
\hline $\begin{array}{l}\text { Perdarahan } \\
\text { Intrakranial }\end{array}$ & 2 & $1,4 \%$ \\
\hline $\begin{array}{l}\text { Adrenocortica } \\
1 \text { Adeno } \mathrm{Ca}\end{array}$ & 1 & $0,7 \%$ \\
\hline Ensefalopati & 1 & $0,7 \%$ \\
\hline Syok & 1 & $0,7 \%$ \\
\hline $\begin{array}{l}\text { Keratogenik } \\
\text { Syok } \\
\text { Neurogenic }\end{array}$ & 1 & $0,7 \%$ \\
\hline $\begin{array}{l}\text { DIC } \\
\quad \text { Jumlah }\end{array}$ & $\begin{array}{c}1 \\
143\end{array}$ & $\begin{array}{l}0,7 \% \\
100 \%\end{array}$ \\
\hline
\end{tabular}

Penyebab kematian kedua terbanyak disebabkan oleh syok sepsis dengan jumlah sebanyak 31 pasien, penyebab kematian terbanyak ketiga disebabkan akibat gagal multi organ dengan jumlah 15 pasien penyebab kematian keempat terbanyak disebabkan oleh syok kardiogenik dengan jumlah sebanyak 13 pasien, penyebab kematian kelima terbanyak disebabkan oleh herniasi tentorial dengan jumlah sebanyak 4 pasien dan sisanya disebabkan oleh syok hipovolemik, mati batang otak dan perdarahan intrakranial yang masing masing jumlahnya sebesar 2 pasien serta penyebab kematian yang paling sedikit disebabkan oleh adrenocortical adeno ca, ensefalopati, syok keratogenik, syok neurogenik dan DIC dengan jumlah masing masing sebanyak 1 pasien (tabel 3).

\section{Usia Pasien PICU yang Meninggal}

Hasil penelitian ini menunjukkan pasien yang meninggal di ruang PICU 
berdasarkan usia yang terbanyak berada pada kategori usia $<60$ bulan sebanyak 73,2\% pada tahun 2016-2017. Hasil Penelitian ini sejalan dengan penelitian di Denpasar yang menyatakan pasien yang meninggal di ruang PICU terbanyak berada pada usia di bawah 60 bulan sebesar 84,2\% (IDAI, 2016). Berdasarkan usia, umur anak kurang dari 60 bulan memiliki risiko meninggal 0,6 kali lebih banyak dari usia di atas 60 bulan (Indradjaja dkk, 2014). Berdasarkan teori pasien yang meninggal di bawah usia 5 tahun lebih banyak karena pengaruh dari sistem imun. Pada usia tersebut sistem imun penjamu belum seutuhnya matur. Tahap perkembangan sistem imun menunjukan bahwa semakin muda usia, semakin sedikit tingkat kematangan sistem imun yang telah dicapai. Dengan demikian, semakin rendah kemampuan eradikasi patogen dapat meningkatkan risiko kematian pada anak usia muda (IDAI, 2016).

\section{Jenis Kelamin Pasien PICU yang Meninggal}

Hasil penelitian didapatkan pasien PICU yang meninggal berdasarkan jenis kelamin di RSUD AWS Samarinda terbanyak adalah laki laki yaitu 83 pasien. Penelitian ini sesuai dengan penelitian Burns et al., di Amerika serikat yang menyatakan bahwa pasien terbanyak yang meninggal di ruang PICU berjenis kelamin laki laki sebesar 55\% (Burns et al, 2014). Hasil ini sesuai dengan penelitian Sudarmadji di RSUP Sanglah Denpasar yang menyatakan jenis kelamin terbanyak adalah laki-laki sebanyak 59,3\% (IDAI, 2016).

Penelitian ini sesuai dengan teori yang menyatakan laki laki lebih banyak yang mengalami mortalitas daripada perempuan karena pada laki laki ditemukan peningkatan risiko prematuritas, sindrom gangguan pernapasan dan pembatasan pertumbuhan intrauterin. Peningkatan risiko mortalitas pada laki-laki bukan hanya pada periode perinatal tetapi juga diseluruh masa hidup (KEMENKES RI, 2014). Penelitian sebelumnya berspekulasi bahwa mortalitas yang dialami laki-laki mungkin disebabkan oleh perbedaan lingkungan hormonal. Tingkat testosteron lebih tinggi daripada perempuan, perbedaan ini mungkin terkait dengan perbedaan biomekanik paru dan perkembangan vaskular serta neurologis pada laki-laki (KEMENKES RI, 2014).

\section{Diagnosis Pasien PICU yang Meninggal \\ Berdasarkan hasil penelitian, pneumonia merupakan diagnosis terbanyak yang mengakibatkan kematian yaitu sebanyak 39 pasien.}

Penelitian ini sesuai dengan penelitian yang menyatakan diagnosis terbanyak sampai saat ini adalah pneumonia yang merupakan penyebab utama kematian balita di dunia. Diperkirakan ada 1,8 juta atau 20\% dari kematian anak diakibatkan oleh pneumonia, melebihi kematian akibat AIDS, malaria dan tuberculosis (Kementerian Kesehatan RI, 2010). Kematian balita yang disebabkan oleh pneumonia tahun 2007 cukup tinggi, yaitu sebesar 15,5\% (Djajakusli dkk, 2017). Demikian juga hasil Survei Demografi dan Kesehatan Indonesia (SDKI), yang melaporkan bahwa prevalensi pneumonia dari tahun ke 
tahun terus meningkat, yaitu $7,6 \%$ pada tahun 2002 menjadi $11,2 \%$ pada tahun 2007 (Djajakusli dkk, 2017). Insiden pneumonia pada anak $\leq 5$ tahun di negara maju adalah 2-4 kasus/100 anak/tahun, sedangkan dinegara berkembang 10-20 kasus/100 anak/tahun.

Pneumonia adalah infeksi jaringan paru-paru (alveoli) yang bersifat akut. Penyebabnya adalah bakteri, virus, jamur, pajanan bahan kimia atau kerusakan fisik dari paru-paru, maupun pengaruh tidak langsung dari penyakit lain. Bakteri yang biasa menyebabkan pneumonia adalah Streptococcus dan Mycoplasma pneumonia, sedangkan virus yang menyebabkan pneumonia adalah adenoviruses, rhinovirus, influenza virus, respiratory syncytial virus (RSV) dan para influenza virus. Terjadinya pneumonia ditandai dengan gejala batuk dan atau kesulitan bernapas seperti napas cepat, dan tarikan dinding dada bagian bawah ke dalam (Kim et al, 2017).

Penyebab pasti pneumonia sulit ditemukan dan memerlukan waktu beberapa hari untuk mendapatkan hasilnya, sedangkan pneumonia dapat menyebabkan kematian bila tidak segera diobati. Sehingga penegakkan diagnosis berdasarkan gejala klinis dan penatalaksanaan awal pneumonia diberikan antibiotika secara empiris (Kementerian Kesehatan RI, 2010).

\section{Gambaran Pasien PICU yang Meninggal Berdasarkan Lama Perawatan di RSUD AWS Samarinda}

Hasil penelitian yang didapatkan pada penelitian ini bahwa lama perawatan di ruang PICU paling lama $>120$ jam pada 69 pasien. Data yang tercatat dari 69 pasien didapatkan diagnosis terbanyak adalah bronkopneumonia dengan penyabab kematian terbanyak adalah gagal nafas.

Hasil penelitian ini sejalan dengan Indradjaja, Suparyatha, Hartawan di RSUP Sanglah Denpasar yang menyatakan lama rawat subjek penelitian pada kelompok meninggal 6 hari (Lacroix \& Cotting, 2005). Hasil penelitian Hadirsman di Padang juga sejalan dengan penelitian ini yang mengatakan bahwa lama perawatan berdasarkan umur pasien didapatkan bahwa usia $<10$ tahun dengan lama perawatan < 7hari memiliki angka mortalitas yang cukup tinggi yakni 88,5\% (Lanetzki et al, 2011). Hasil penelitian Horowitz et al mengatakan bahwa pada 225 anak yang sakit terdapat 51 pasien yang meninggal dengan lama rawat inap 8 hari dan memiliki albumin yang rendah (Lassmann et al, 2018).

Lama rawat anak di PICU terdapat banyak hal yang mempengaruhinya hingga sampai anak tersebut meninggal yaitu diagnosis penyakit terutama penyakit infeksi (pneumonia), meningoensefalitis, diare akut, dehidrasi berat, kemudian kadar serum albumin pada pasien, perjalanan penyakitnya yang bisa mengakibatkan Multiple Organ Dysfunction Organ (MODS) (Meilyana et al, 2010 ; Miftahurrohmah, 2008 ; and O’Driscoll et al, 2017).

Penyebab Kematian Pasien PICU yang Meninggal di RSUD AWS Samarinda

Berdasarkan hasil penelitian ini didapatkan pasien PICU yang meninggal berdasarkan penyebab kematian di RSUD AWS Samarinda terbanyak yaitu 
pasien yang disebabkan oleh gagal napas dengan jumlah sebanyak 67 pasien.

Penelitian ini sejalan dengan penelitian Burns et al., di Amerika serikat yang menyatakan bahwa pasien terbanyak yang meninggal di ruang PICU penyebab kematianya disebabkan oleh gagal napas (Burns et al, 2014). Penelitian ini juga sesuai dengan penelitian yang dilakukan oleh Djajakusli di RSUD dr Soetomo Surabaya yang menyatakan bahwa gagal napas merupakan penyebab kematian terbanyak pertama dengan jumlah sebanyak $78,2 \%$ dan terbanyak kedua adalah sepsis (Ralston et al, 2006). Penelitian ini juga didukung oleh penelitian Miftahurrohmah di RSUD AWS Samarinda yang menyatakan gagal napas merupakan penyebab kematian terbanyak diruang PICU (Ralston et al, 2006).

Teori menyatakan bahwa masalah kegawatan yang paling sering dialami bayi dan anak adalah gangguan pernapasan, gangguan perfusi perifer dan perubahan kesadaran dimana kegawatan pernapasan yang terbanyak yaitu gagal napas akut merupakan $50 \%$ penyebab kematian terbanyak di ruang PICU (Kliegman et al, 2000 ; and Hardisman, 2008). Gangguan pertukaran oksigen dan karbondioksida merupakan salah satu penyebab mobiditas dan mortalitas terbesar pada bayi dan anak yang dirawat diruang PICU di RSCM Jakarta. Hal ini terjadi karena bayi dan anak anak memiliki struktur anatomi yang berbeda dengan orang dewasa, hal ini merupakan salah satu prediposisi seringnya terjadi problem pernapasan pada bayi dan anak. Selain itu bayi dan anak memiliki kerentan terhadap infeksi saluran pernapasan. Hal ini menyebabkan sistem pernapasan tidak mampumemenuhi kebutuhan metabolisme tubuh (Said M, 2008).

Mekanisme gagal napas menggambarkan ketidakmampuan tubuh untuk melakukan oksigenasi dan/atau ventilasi dengan adekuat yang ditandai oleh ketidakmampuan sistem respirasi untuk memasok oksigen yang cukup atau membuang karbon dioksida. Pada gagal napas terjadi peningkatan tekanan parsial.

karbon dioksida arteri (PaCO2) lebih besar dari $50 \mathrm{mmHg}$, tekanan parsial oksigen arteri $(\mathrm{PaO} 2)$ kurang dari 60 $\mathrm{mmHg}$, atau kedua-duanya. Hiperkarbia dan hipoksia mempunyai konsekuensi yang berbeda (Staf Pengajar Ilmu Kesehatan Anak, 1985 ; dan Stenklft et al, 2007).

\section{SIMPULAN}

Dari hasil diatas dapat disimpulkan bahwaangka kejadian pasien yang dirawat di ruang PICU RSUD Abdul Wahab Sjahranie Samarinda periode 2016-2017 adalah sebanyak 282 pasien, angka kejadian pasien yang meninggal sebanyak $67,4 \%$, Usia pasien yang meninggal terbanyak pada usia $<60$ bulan sebanyak $49,3 \%$ dan $\geq 60$ bulan sebanyak $18,1 \%$, jenis kelamin pasien yang meninggal terbanyak adalah jenis kelamin laki-laki sebanyak $34,4 \%$ dan perempuan sebanyak $32,9 \%$, diagnosis pasien yang meninggal adalah pneumonia dengan jumlah sebanyak $27,3 \%$, lama perawatan pasien yang meninggal $>120$ jam dengan jumlah sebanyak $48,3 \%$, penyebab kematian pasien yang meninggal adalah gagal napas sebanyak $48,2 \%$. 


\section{DAFTAR PUSTAKA}

Aisyah, 2010. Hubungan Kadar Laktat Darah dan Skor PELOD terhadap Mortalitas Pasien di PICU RSUD dr. Moewardi Surakarta. Surakarta: Universitas Sebelas Maret.

Alfana , M. A. F., Hanif , W. A. N. P. \& Iffani , M., 2015. Mortalitas di Indonesia (Sejarah Masa Lalu dan Proyeksi ke Depan). s.l., s.n.

Barry, P., Morris, K. \& Ali, T., 2010. Paediatric Intensive Care. s.1.:Oxford Medical Publications.

Brooten, D. et al., 2016. Cause of Death of Infants and Children in the Intensive Care Unit: Parents' Recall vs Chart Review. American journal of critical care : an official publication, American Association of Critical-Care Nurses, 25(3), pp. 235-242.

Burns, J. P. et al., 2014. Epidemiology of Death in the Pediatric Intensive Care Unit at Five U.S. Teaching Hospitals. Critical Care Medicine.

Djajakusli, S., Harianto, A., Etika, R. \& Martono, T., 2017. Profil Kematian Neonatus di RSUD dr. Soetomo. Sari Pediatri, 18(6), pp. 474-480.

El Hamshary, A. A. E., Sherbini, S. A. E., Elgebaly, H. F. \& Amin, S. A., 2016. Prevalence of multiple organ dysfunction in the pediatric intensive care unit: Pediatric Risk of Mortality III versus Pediatric Logistic Organ Dysfunction scores for mortality prediction. Revista Brasileira De Terapia Intesiva, 21 May.
Frankel, L. R. \& DiCarlo, J. V., 2003. Pediatric Intensive Care. In: Pediatrics for Medical Students. s.l.:s.n., p. 541.

Hardisman, 2008. Lama Rawatan dan Mortalitas Pasien Intensive Care Unit (ICU) RS Dr. Djamil Padang Ditinjau dari Beberapa Aspek. pp. 142-150.

Horowitz, I. N. \& Kenneth, T., 2007. Hypoalbuminemia in Critically Ill Children. American Medical Association, 161(11), pp. 10481052.

IDAI, 2016. Konsensus Diagnosis dan Tata Laksana Sepsis pada Anak. s.1.:Badan Penerbit Ikatan Dokter Anak Indonesia.

Indradjaja, A., Suparyatha, I. B. \& Hartawan, I. N. B., 2014. HUBUNGAN ANTARA KADAR ALBUMIN DAN MORTALITAS PASIEN DI UNIT PERAWATAN INTENSIF ANAK RSUP SANGLAH DENPASAR. Medicina, 45(1), pp. 13-18.

KEMENKES RI, 2014. Profil Kesehatan Indonesia Tahun 2013.

Kementerian Kesehatan RI, 2010. Pneumonia Balita. Buletin Jendela Epidemiologi, Volume 3.

Kim, Y. S. et al., 2017. Serum Albumin as a Biomarker of Poor Prognosis in the Pediatrics Patients in Intensive Care Unit. Korean J Crit Care Med, pp. 347-355.

Kliegman, R. M., Behrman, R. E. \& Stanton, B. F., 2000. Nelson Textbook of Pediatrics. Jakarta: EGC. 
Lacroix, J. \& Cotting, J., 2005. Severity of illness and organ dysfunction scoring in children. Pediatr Crit Care Med, Volume 6, pp. 126127.

Lanetzki , C. S. et al., 2011. The epidemiological profile of Pediatric Intensive Care Center at Hospital Israelita Albert Einstein. p. 16.

Lassmann, L. et al., 2008. Communityacquired Pneumonia in Children in Lambarene, Gabon. Am. J. Trop Med, pp. 109-113.

Meilyana, F., Djais, J. \& Garna, H., 2010. Status Gizi Berdasarkan Subjective Global Assessment Sebagai Faktor yang Mempengaruhi Lama Perawatan Pasien Rawat Inap Anak. Sari Pediatri, oktober, Volume 12, pp. 163-166.

Miftahurrohmah, 2008. Gambaran Pasien yang Dirawat di Ruang PICU RSUD Abdul Wahab Sjahranie Samarinda Tahun 2006. Samarinda: s.n.

O'Driscoll, D. N., Greene, C. M. \& Molloy, E. J., 2017. Immune function? A missing link in the gender disparity in preterm neonatal outcomes. Expert Review of Clinical Immunology, oktober.

Ralston, M., Hazinski, M., Zaritsky, A. $\&$ et al, 2006. Pediatric Assesment. In: Pediatric Advanced Life Support, Provider Manual. Dallas: American Heart Association, pp. 1-32.

RISKESDAS, 2008. Laporan Nasional 2007. Jakarta: Badan Penelitian dan Pengembangan Kesehatan
Departemen Kesehatan Republik Indonesia.

Said, M., 2008. Pneumonia. In: Buku Ajar Respirologi Anak. Jakarta: Badan Penerbit IDAI, p. 350.

Staf Pengajar Ilmu Kesehatan Anak, 1985. Ilmu Kesehatan Anak Jilid 3. Jakarta: Infomedika.

Stenklyft, P. H., Cataletto, M. E. \& Lee, B. S., 2007. The Pediatric Airway in Health and Disease. In: The Pediatric Emergency Medicine Resource. 4 ed. Boston: Jones and Barlett Publishers, p. 53.

Sudarmadji, S., Wati, D. K. \& Sidiartha, L., 2016. Faktor Risiko pada Lama Rawat dan Luaran Pasien Perawatan di Unit Perawatan Intensif Anak RSUP Sanglah Denpasar. Sari Pediatri, April, Volume 17, pp. 456-459.

Sudiono, J., 2014. Sistem Kekebalan Tubuh. s.l.:EGC.

Susianawati, V., Suryantoro, P. \& Naning, R., 2014. Prognostic predictor at Pediatrics Intensive Care Unit (PICU) with Pediatric Risk of Mortality III (PRISM III) scores. J Med Sci, Juni, Volume 46, pp. 71-76.

Torres, A., 2015. When Your Child's in the Pediatric Intensive Care Unit. [Online]

Available at: http://kidshealth.org/en/parents/p icu.html\# [Accessed 4 December 2017].

WHO, 2006. Pneumonia: the forgotten killer of children. [Online].

WHO, 2009. Diarrhoea: Why Children Are Still Dying And What Can Be Done. [Online] Available at: 
JURNAL MUTIARA MAHAKAM VOL VII, NO 1, MARET 2019

http://apps.who.int/iris/bitstream/

handle/10665/44174/978924159

$\underline{8415 \text { eng.pdf }}$

[Accessed Januari 2018].

Zhao, D., Zou, L., Lei, X. \& Zhang, Y., 2017. Gender Di erences in Infant Mortality and Neonatal Morbidity in Mixed-Gender Twins. Scientific Reports, Agustus.pp. 1-4. 